\title{
Immunodeficiency due to interleukin-1 receptor-associated kinase-4 deficiency
}

INSERM

\section{Source}

INSERM. (1999). Orphanet: an online rare disease and orphan drug data base.

Immunodeficiency due to interleukin-1 receptor-associated kinase-4 deficiency.

ORPHA:70592

Interleukin-1 receptor-associated kinase-4 (IRAK-4) deficiency is an immunodeficiency associated with increased susceptibility to invasive infections caused by pyogenic bacteria. 